ORIGINAL ARTICLE

\title{
Evaluation of Mortality of Patients with Neonatal Tetanus
}

Taslim S. Soetomenggolo, Hardiono D. Pusponegoro, Jimmy Passat, Sofyan Ismael

(Department of Child Health, Medical School, University of Indonesia, Jakarta )

Aastract During 8 years, 405 patients of neonatal tetanus were hospitalized in the Department of Child Health, Cipto Mangunkusumo Hospital, Jakarta. Diagnosis of neonatal tetanus was based on clinical signs and symptoms. Of the 405 patients, $56.3 \%$ were males and $43.7 \%$ were females. Two hundreds and sixty nine $(66.3 \%)$ patients were delivered by traditional birth attendants, and only $33.6 \%$ were delivered by midwives or physicians. The overall mortality was $54.4 \%$, with the corrected mortality of $46.7 \%$. Severity of the disease, short incubation period, short period of onset, and the accompanying diseases were responsible for the high mortality of patients with neonatal tetanus. [Paediatr Indones 1994; 34:136-140]

\section{Introduction}

The case fatality rate of neonates with tetanus treated with conventional drug is very high:, ${ }^{1.5}$ in Indonesia the fatality rate is as high as 35-96\% $\%^{6-12}$ This high case fatality rate depends on the severity of the disease, short incubation period, short period of onset, and presence of accompanying diseases. ${ }^{1,5,11,12,16}$ Actually the mortality of patients with tetanus

Received for publication: July 26, 1993. For correspondence:- T. S. Soetomenggolo, MD, Department of Child Health, Medical School, University of Indonesia, Jalan Salemba 6, Jakarta 10430, Indonesia. Tel. (62)(21) $390-7741$; Fax 390-7743 could be decreased by treating them with neuromuscular blocking agents and with intermitent positive-pressure ventilation in the intensive care unit (ICU). By this method the case fatality rate is $0-23.3 \%{ }^{13-15}$ However, the cost of such treatment is very high, and it is beyond the ability of most hospitals in Indonesia, due to shortages of equipment and medical personnels. As most neonates with tetanus come from low socioeconomic level, it is imposible for the parents to afford such a high cost. The aim of this study was to evaluate the mortality of patients with neonatal tetanus and factors contributing to it.

\section{Methods}

During 8-year period (197.8-1985), 405 neonates with tetanus were hospitalized at the Department of Child Health, Cipto Mangunkusumo Hospital, Jakarta. The diagnosis of neonatal tetanus was based on clinical symptoms and signs. All of these 405 cases were given the same treatment, i.e.:

- Intravenous fluid drip (IVFD) with 5\% glucose : physiologic saline $4: 1$ in the first 48-72 hours. Thereafter they were fed through a gastric tube. The IVFD was maintained for the administration of intravenous drugs.

- Ampicillin in a dose of $100 \mathrm{mg} / \mathrm{kgBW} /$ day plus gentamicin $5 \mathrm{mg} / \mathrm{kgBW} /$ day were given by intravenous injection for ten days.

- Intramuscular anti tetanus serum (ATS) was administered with the dose of 10000 units/day for two days.

- Diazepam $2.5 \mathrm{mg}$ was given by slow intravenous injection, followed by 8$10 \mathrm{mg} / \mathrm{kgBW} /$ day via the IVFD. IVFD solution was renewed every 6 hours. Diazepam $2.5 \mathrm{mg}$ was administered intravenously when prolonged spasms recurred. This was replaced by oral route as the patient became better.

- Treatment of the umbilical cord was restricted to cleaning of the stump with $70 \%$ alcohol solution.

- Cleaning of the respiratory tract was done during and after each spasm; care was exercised to avoid excessive stimulation that may induce further spams.

- Oxigen was given freely through nasopharyngeal canule when necessary, mainly in prolonged spasm.

\section{Results}

Of the 405 patients, 228 (56.3\%) were males and 177 (43.7\%) were females. Two hundred and sixty nine (66.4\%) of patients were delivered with the assistance of traditional birth attendants, and $136(33.6 \%)$ were assisted by midwives or physicians. The overall mortality of the 405 patients in this series was 220 (54.3\%). Among the 220 non-survivors, 39 died on the first day of hospitalization. If these 39 patients were excluded from evaluation, the total remaining patients were 366,181 of them died. Actually 10 of the 181 non-survivors had recovered from tetanus, and the death was caused by other diseases. If they were also excluded, then the corrected case fatality rate was $171 / 366$ (46.7\%).

Table 1 depicts the relationship between mortality and severity of the disease. There were 7 patients with mild, 13 patients with moderate, and 385 patients with severe tetanus. All patients with mild and moderate cases recovered from the disease, while all 220 nonsurvivors belonged to severe group.

Table 1. Relation of mortality and severity of the disease

\begin{tabular}{lrrrr}
\hline Cinical severity & $\begin{array}{c}\text { No of } \\
\text { pts }\end{array}$ & \% & Died & $\%$ \\
\hline Mild & 7 & 1.7 & 0.0 & 0.0 \\
Moderate & 13 & 3.2 & 0.0 & 0.0 \\
Severe & 385 & 95.1 & 220 & 57.1 \\
\hline Total & 405 & 100 & 220 & \\
\hline
\end{tabular}

Table 2 shows the relationship between the incubation period and mortal- 
ity. It is clearly shown that patients who had incubation period of less than 7 days had a high : tient with the incubrition period of more than 10 days had died.

Table 2. Relationship between incubation period and mortality

\begin{tabular}{crrrr}
\hline $\begin{array}{c}\text { Incubation } \\
\text { period (days) }\end{array}$ & $\begin{array}{c}\text { No of } \\
\text { pts }\end{array}$ & $\%$ & Mortality & $\%$ \\
\hline 3 & 17 & 4.2 & 16 & 94.1 \\
4 & 59 & 14.6 & 53 & 89.8 \\
5 & 88 & 21.7 & 65 & 73.9 \\
6 & 102 & 25.2 & 62 & 60.7 \\
7 & 40 & 9.9 & 10 & 25.0 \\
8 & 37 & 9.1 & 92 & 4.3 \\
9 & 26 & 6.4 & 41 & 5.4 \\
10 & 11 & 2.7 & 1 & 9.1 \\
11 & 9 & 2.2 & 0 & 0.0 \\
12 & 8 & 2.0 & 0 & 0.0 \\
13 & 3 & 0.8 & 0 & 0.0 \\
14 & 5 & 1.2 & 0 & 0.0 \\
\hline Total & 405 & 100 & 220 & \\
\hline
\end{tabular}

Table 3 depicts the relationships between the incubation period (less than 7 days or 7 days or more) and the mortality. The number of patients with the incubation period of less than 7 days was $266,196(73.7 \%)$ of them died, while of 139 patients with the incubation period of 7 days or more only $24(17.3 \%)$ died. When hypothesis testing by using independent Chi-square tset was carried out, it was shown that there was a very significant difference between the two groups.
Table 3. Comparison of mortality and incubation period less than 7 days and 7 days or more

\begin{tabular}{cccrc}
\hline $\begin{array}{l}\text { Incubation peri- No of } \\
\text { od (days) }\end{array}$ & $\begin{array}{l}\text { Reco- } \\
\text { pts }\end{array}$ & vered & Died & $\begin{array}{c}\text { Mortality } \\
\text { (\%) }\end{array}$ \\
\hline$<7$ & 266 & $\cdot 70$ & 196 & $73.7 \%$ \\
$\geq$ & 139 & 115 & 24 & $17.3 \%$ \\
\hline Total & 405 & 185 & 220 & \\
\hline
\end{tabular}

$x^{2}=121.47 ; p<0.001$

Table 4 shows the relationship between the period of onset and mortality. Of the 377 patients with period of onset of 24 hours or less 218 patients $(57.8 \%)$ died, while 21 patients with period of onset more than 24 hours only two patients $(9.5 \%)$ died. Chi-square testing showed that this difference was very significant.

Table 4. Relationship between period of onset and mortality

\begin{tabular}{crrrr}
\hline $\begin{array}{c}\text { Period } \\
\text { of onset }\end{array}$ & $\begin{array}{c}\text { No of } \\
\text { pts }\end{array}$ & Recovered & Died & $\begin{array}{c}\text { Mortality } \\
(\%)\end{array}$ \\
\hline$\leq 24$ hrs & 377 & 159 & 218 & 57.8 \\
$>24$ hrs & 21 & 19 & 2 & 9.5 \\
\hline Total & \multicolumn{1}{c}{398} & 178 & 220 & \\
\hline $\mathrm{X}^{2}=18.77$ & $\mathrm{P}<0.001$ & &
\end{tabular}

Table 5 depicts the relationship between patients' mortality and the presence of the accompanying diseases. It is evident from the table that the most frequently found diseases complicating neonatal tetanus that associated with patients' mortality were bacterial meningitis, aspiration pneumonia, low birth weight, and some forms of congenital heart disease with cardiac failure.
Table 5. Relationship between the accompanying diseases and mortality

\begin{tabular}{lrrrr}
\hline Disease & $\begin{array}{c}\text { No of } \\
\text { pts }\end{array}$ & $\begin{array}{r}\text { Reco- } \\
\text { vered }\end{array}$ & Died & $\begin{array}{c}\text { Mortal- } \\
\text { ity }(\%)\end{array}$ \\
\hline Septicemia & 57 & 29 & 28 & 49.1 \\
$\begin{array}{l}\text { Dehydration } \\
\text { Bronchopneu- } \\
\text { monia }\end{array}$ & 22 & 16 & 16 & 50.0 \\
$\begin{array}{l}\text { Bacterial } \\
\text { meningitis }\end{array}$ & 15 & 3 & 12 & 80.0 \\
$\begin{array}{l}\text { Aspiration } \\
\text { pneumnia }\end{array}$ & 9 & 1 & 8 & 88.9 \\
$\begin{array}{l}\text { Gastroenteritis } \\
\text { with dehydration }\end{array}$ & 8 & 7 & 1 & 12.5 \\
$\begin{array}{l}\text { Low birth } \\
\text { weight }\end{array}$ & 60 & 61 & 0 & 0.0 \\
$\begin{array}{l}\text { CHD with } \\
\text { heart failure }\end{array}$ & 20 & 21 & 0 & 0.0 \\
Hepatitis & 2 & 0 & 0 & 0.0 \\
\hline
\end{tabular}

\section{Discussion}

Our data indicated that out of the 405 patients, $269(66.4 \%)$ were delivered by traditional birth attendants, while only $33.7 \%$ were delivered by midwives or physicians. This finding was similar to other from previously reports, and was most likely related to the low socioeconomic level of most of patients. . $^{7,9,11,12,17-21}$

The overall mortality of this study was $54.3 \%$ but after correcting the data, the mortality was $46.7 \%$. This figure was still very high, but if we compared with the data before the use of intravenous diazepam, the difference was statistically very significant. Before using diazepam, since January 1, 1974 until August 31, 1977 we hospitalized 473 neonatal tetanus patients, and $415(87.7 \%)$ of them died. ${ }^{22}$ The mortality of this study was also not quite different with other studies. Husada (1976), Soetomenggolo (1981), and Sugitha (1983) and co-workers reported the fatality of $50 \% a^{11,12,19}$ Table 1 shows all of mild and moderate cases recovered, while 220 of the 385 severe cases died. This is similar to other previously published reports. ${ }^{1-3,9-12,23,24}$

Tables 2 and 3 show that the incubation period is an important factor which contributes to the case fatality rate. Patients with the incubation period of less than 7 days showed a significantly higher mortality than those with the incubation period of 7 days or more. This is similar to other studies. ${ }^{1-3,7,9,11,12,21,24}$

From Table 4 we can see the relationship between the period of onset and mortality. Period of onset is the time between the first symptom of tetanus and convulsion.' According to Jenkins and Luhn, ${ }^{25}$ mild tetanus is defined as tetanus without convulsion; consequently, by definition this patient is without period of onset. Table 1 shows 7 patients suffered from mild tetanus. The rest 398 patients with moderate and severe tetanus have period of onset. Table 4 shows that the difference between the fatality rate of patients with period of onset 24 hours or less and those with the period of onset of more than 24 hours was statistically significant. This finding was similar to other studies. ${ }^{1,11,12}$

Table 5 shows that the most frequent accompanying diseases were infections, which were usually caused by gram positive and gram negative bacteria. ${ }^{16}$ For this reason we added gentamicin in this treatment. 


\section{References}

1. Patel JC, Joag GG. Grading of tetanus to evaluate prognosis. Indian $\mathrm{J}$ Med Sci 1959; 13: 834-40.

2. Athavale VB, Pai PN. Tetanus neonatorum; Clinical manifestations. Trop Pediatr 1965; 67: 649-57.

3. Hendrickse RG, Sherman PM. Report of a therapeutic trial of diazepam $\mathrm{Br}$ Med J $1966 ; 2: 860-2$.

4. Balakrishnan S, Radhakrishna S. Neonatal tetanus. J Pediatr Obst Gynaec 1983; 11-6.

5. Salimpour R. Cause of death in tetanus neonatorum. Arch Dis Child 1977; 52: 587-9.

6. Sunarto, Budiman D. Valium in the treatment of tetanus neonatorum. Pediatr Indones 1972; 12:22-8.

7. Tjay JK, Sembiring L. Modified treatment of neonatal tetanus. Paediatr Indones 1972; 12:229-34.

8. Marwoto, Surjono A. Tetanus neonatorum in the Bethesda Hospital Yogyakarta. Paediatr Indones 1976; 16:337-44.

9. Husada TJ, Rampengan. TM, Harjanto IGN, Arif ID, Munir M. Neonatal tetanus Evaluation of treatment and a proposal for classification of severity. Paediatr Indones 1976; 16:345-54.

10. Ruspanji T. Peranan keluarga pada perawatan tetanus neonatorum, Naskah lengkap Diskusi Kelompok Tetanus Neonatorum, Konika V, Medan, 1981.

11. Soetomenggolo T'S, Purboyo RH, Hendarto SK, Ismael S. Neonatal tetanus treated with diazepam as a single antispasmodic agent. Paediatr Indones 1981; 21:101-6.

12. Sugitha N, Suwendra P, Suraatmaja S. High dosage diazepam as single antispasmodic agent in treatment of neonatal tetanus. Paediatr Indones 1983; 23: 163- 72.

13. Ganendran A. Intensive therapy in neonatal tetanus. Anesthesia $1974 ; 29: 356-$ 62.
14. Smythe PM, Bowie MD, Voss TJV. Treatment of tetanus neonatorum with muscle relaxants and intermittent positive-pressure ventilation. Br Med J 1974; 1:223-6.

15. Adams JM, Kenny JD, Rudolph AJ. Modern management of tetanus neonatorum. Pediatrics 1979; 64: 472-7.

16. Phatak AT, Shah SB. Indices of severity of neonatal tetanus. Indian Pediatr 1973; 10: 87-91.

17. Liem WT, Darmawan S, Ismael $S$, et al. The effect of diazepam on tetanus. Paediatr Indones 1970; 10: 248-58.

18. Retno Trenggonowati, Darmawan S, Kasim YA. The effect of nitrazepam (Mogadon) on tetanus as compared with diazepam. Paediatr Indones 1971; 11: 201-11.

19. Husada TJ, Munir M. Neonatal tetanus; an analysis of 108 cases using a scoring. Proc Second Asian Cong Paediatr Jakarta, 3-6 August, 1976.

20. Husada TJ, Munir M. Failure of high dosage of valium in the treatment of neonatal tetanus. Paediatr Indones 1980; 20: 51-6.

21. Tjut Dharmawati, Rizal F, Lubis M, Joel C, Pasaribu S, Lubis CP. Treatment of neonatal tetanus with high dosage diazepam. Paediatr Indones 1993; 33:71-6.

22. Soetomenggolo TS. Patients with neonatal tetanus in the Department of Child Health, Dr. Cipto Mangunkusumo Hospital Jakarta, 1974-1977. Unpublished data.

23. Khoo BH, Lee EL, Law KL. Neonatal tetanus treated with high dosage diazepam. Arch Dis Child 1978; 53: 737-9.

24. Neequaye J, Nkrumah FK. Failure of intrathecal antitetanus serum to improve survival in neonatal tetanus. Arch Dis Child 1983; 58: 276-8.

25. Jenkins MT, Luhn RN. Active management of tetanus based on experiences of on anesthesiology department, Anesthesiology 1962; 23: 690 (Cited by FemiPearse, 1966).

26. Femi-Pearse D. Experience with diazepam in tetanus. Br Med J 1966; 2: 862-5. 